\title{
Microhabitat Characteristics of Lapland Longspur, Calcarius lapponicus, Nests at Cape Churchill, Manitoba
}

\author{
Clint W. BoAl ${ }^{1,2}$ and David E. ANDERSEN ${ }^{3}$
}

${ }^{1}$ U.S. Geological Survey Texas Cooperative Fish and Wildlife Research Unit, Texas Tech University, Lubbock, Texas, 794092120 USA

${ }^{2}$ Corresponding author: email: clint.boal@ttu.edu

${ }^{3}$ U.S. Geological Survey Minnesota Cooperative Fish and Wildlife Research Unit, University of Minnesota, St. Paul, Minnesota 55108, USA

Boal, Clint W., and David E. Andersen. 2005. Microhabitat characteristics of Lapland Longspur, Calcarius lapponicus, nests at Cape Churchill, Manitoba. Canadian Field-Naturalist 119(2): 208-213.

We examined microsite characteristics at 21 Lapland Longspur (Calcarius lapponicus) nests and land cover types in which they occurred in Wapusk National Park, Cape Churchill, Manitoba. Nests were located in four of six physiographic-vegetation land-cover types. Regardless of land-cover type, all but one nest was built on a pressure ridge or mound. Nests were built midway between the bottom and top of ridges or mounds with steeper slopes than was randomly available. Longspur nests had a distinctive southwest orientation $(P<0.001)$. Longspurs selected nest sites that consisted of comparatively greater amounts of shrub species and lesser amounts of moss than were randomly available. Nests were generally well concealed by vegetation (mean $=67.0 \%)$ and concealment was negatively associated with amount of graminoid species at the nest $(P=0.0005)$. Our nesting habitat data may facilitate a better understanding of breeding Lapland Longspur habitat requirements, and potential impacts of habitat degradation by increasing Snow Goose (Chen caerulescens) populations in the study area.

Key Words: Calcarius lapponicus, Lapland Longspur, Chen caerulescens, Lesser Snow Goose, microhabitat, Cape Churchill, nesting habitat, Manitoba.

The Lapland Longspur (Calcarius lapponicus) is one of the most common breeding passerines of the Arctic (Rising 1996; Gilg et al. 2000; Henry and Mico 2002; Hussell and Montgomerie 2002), with a wide distribution across well-vegetated tundra landscapes of North America and Eurasia (Hussell and Montgomerie 2002). However, because breeding by Lapland Longspurs occurs outside of the Breeding Bird Survey (Dunn 1997), little information is available concerning population trends (Hussell and Montgomerie 2002). The species has experienced substantial population declines in the region of Churchill, Manitoba, since the 1930s (Taverner and Sutton 1934; Jehl and Smith 1970; J. R. Jehl, in Hussell and Montgomerie 2002). It is now reported to be absent from the area except in small, scattered groups along the coast to Cape Churchill (Hussell and Montgomerie 2002).

Understanding a species' habitat requirements is a key element of understanding population trends. Unfortunately, most nesting habitat data for Lapland Longspurs are qualitative. Breeding Lapland Longspurs are reported as most common in wet tundra, thickly vegetated uplands, sedge margins along streams and ponds, and hummocks and sedges in marshes (Rodrigues 1994; Rising 1996; Henry and Mico 2002). Nests are typically placed in a depression in the ground on the side of a bank or hummock (Hussell and Montgomerie 2002), and consist of a cup of coarse sedges, grasses, moss, and roots lined with finer materials such as feathers, hair, and finer grasses (Watson 1957; Rising 1996; Baicich and Harrison 1997). However, few quantitative data are available on nest dimensions (Brandt 1943; Grinnell 1944; Madsen 1981), orientation (Rodrigues 1994), vegetation characteristics (Rodrigues 1994), or nest concealment of Lapland Longspur nests, all of which may relate to nest thermal conditions and concealment and, thereby, nesting success. Such information is necessary to develop a more complete understanding of the species' breeding habitat requirements. Nesting habitat information may also facilitate a better understanding of possible factors leading to local population trends. Existing data for Lapland Longspurs are primarily from the northern portions of the species' breeding range (see Hussell and Montgomerie 2002 for review). Fewer published data are available from the more southerly extent of the species' range, and those available are dated (Taverner and Sutton 1934; Grinnell 1944; Jehl and Smith 1970). Here we present data on microhabitat characteristics of Lapland Longspur nests at Cape Churchill, Manitoba, in June 2003. This coincided with the peak of nesting activity by the species in the area.

\section{Study Area}

The study area center is approximately $2 \mathrm{~km}$ west of Hudson Bay in Wapusk National Park, and situated $35 \mathrm{~km}$ east of Churchill, Manitoba and $15 \mathrm{~km}$ southeast from La Pérouse Bay $\left(58^{\circ} 39^{\prime} \mathrm{N}, 93^{\circ} 11^{\prime} \mathrm{W}\right)$. The study area is characterized as a tundra biome, consisting of a series of coastal salt marshes, willow (Salix spp.) and spruce (Picea spp.) patches, beach ridges, and an inland matrix of large, permanent freshwater lakes, 
ephemeral freshwater pools, and freshwater sedge meadows (Didiuk and Rusch 1979). We characterized the landscape into physiographic-vegetation communities as described by Henry and Mico (2002). Wet Sedge Meadows (WSM) were typically level, hydric lowlands with nearly continuous sedge cover and often shallow surface water. Graminoid Tundra (GRT) was mesic to hydric areas with near-continuous graminoid cover and occasional dwarf shrubs (primarily Salix spp.). Graminoid/Dwarf Shrub Tundra (GST) consisted of $75-100 \%$ cover of graminoids and moss, with herbs and dwarf shrubs on the occasional drier earthen hummocks. Common features of the inland matrix are low pressure ridges and mounds (i.e., earthen hummocks) created when surface ice expands during the winter and pushes peat upward (Johnson 1987). These mounds and ridges support herbs, moss, dwarf shrubs, and in lower areas, some graminoids. Some areas consisted exclusively of these mounds and ridges, and were classified as Hummocky Tundra (HT). Dwarf Shrub Tundra (DST) occurred primarily on moist but welldrained slopes, and consisted of about $50-75 \%$ cover dominated by dwarf shrubs. Dwarf Shrub/Lichen Barrens (DLB) were windblown sites at higher elevations (e.g., beach ridges), and typically had low (25-50\%) vegetation cover. All of these descriptions are from Henry and Mico (2002), modified to apply to our study area.

\section{Methods}

Intensive nest searches were conducted in one 6-ha plot (North Plot) and one 3.7-ha plot (South Plot). The North Plot was primarily a HT, but the west border also consisted of GRT and WSM. The South Plot was primarily GRT with patches of HT and WSM. Intensive nest searches consisted of walking transects across the plot, watching and following longspurs observed carrying nest material, prey, or engaged in other behaviors indicative of a nearby nest, or flushing females from nests. Transects were closely spaced (e.g., approximately $20 \mathrm{~m}$ apart) but inter-transect distances and linearity were variable due to pools and ponds in the search areas.

The majority of Lapland Longspur nests was not located systematically. Rather, many nests were found when researchers engaged in other studies inadvertently flushed longspurs from nests, or followed longspurs observed carrying nesting material or prey.

A handheld GPS unit was used to record the UTM coordinates of each nest site and a flag was placed $10 \mathrm{~m}$ north of each nest to facilitate relocation. The vegetation community at the nest site and the structure (i.e., hummock, pressure ridge) in which the nest was built was recorded. The height of the nest above the base of the structure and height of the structure, slope of the structure, and orientation of the nest were recorded. Nest width and depth were recorded if such measurements would not physically disturb the nest or contents. To compare nest orientation to wind patterns, we cal- culated the percent of time the wind was out of the north, northeast, east, southeast, south, southwest, west, and northwest from daily records at the Nester One field station during the period of 3-24 June 2003.

To assess microhabitat vegetation at nest sites, a $20-\mathrm{cm}$ by $20-\mathrm{cm}$ frame was centered on the nest and a digital photograph was taken from $1.5 \mathrm{~m}$ above the nest. Each digital image was imported into Adobe Photoshop 7.0 and overlaid with a $1-\mathrm{cm} \times 1-\mathrm{cm}$ grid $(100$ intersecting points). The vegetation species at each intersection was identified using collected samples and published references (Johnson 1987). Proportions of each vegetation species and litter were calculated. Identical measurements were made at paired random sites situated $10 \mathrm{~m}$ away and in a random direction from each nest.

We used Adobe Photoshop 7.0 to select the specific circular or elliptical area of each nest from the digital image. We then resized the image so that the narrowest span across the nest was $10 \mathrm{~cm}$. Width of each image varied slightly because not all nests were perfectly circular. The image was then overlaid with a $0.5-\mathrm{cm}$ by 0.5 -cm grid, resulting in approximately $280-300$ intersecting points. The substrate under each intersecting point was identified as vegetative cover or nest/nest contents. Percent nest cover (i.e., concealment) was then calculated as the proportion of all points identified as cover vegetation.

Descriptive statistics for nest dimensions, height, slope, orientation, and concealment are provided. We used methods described by Zar (1999) to calculate the mean bearing and 95\% Confidence Interval for nest orientation. We used Rayleigh's test for uniformity to test the hypothesis that nest orientation was not random (Zar 1999). Correlation analysis was conducted to examine relationships between principal vegetation cover types and nest concealment. Rather than significance testing, we compared proportions of vegetation species at nest and random sites with $95 \%$ Confidence Intervals (Johnson 1999). Descriptive statistics reported include means and standard deviations. All statistical analyses were conducted using program STATISTICA 6.0 .

\section{Results}

We located 21 active Lapland Longspur nests in the study area. Eight of the nests were located in the intensively surveyed plots, and nesting density in the two survey plots was similar ( 0.83 nests/ha and 0.81 nests/ ha). Nearest nesting distance of any two nests was $39.5 \mathrm{~m}$. Nests were located in 4 of the 6 physiographicvegetation types. Eight nests were in GST (38\%), six each were located in GRT (28.6\%) and HT (28.6\%), and one was located in DLB (4.8\%). Despite the physiographic-vegetation types where nests were found, all but one nest were built on the side or top of a pressure ridge $(38.1 \%)$ or mound $(57.1 \%)$; the exception was one nest located in a grass hummock on a beach ridge (i.e., DLB). 


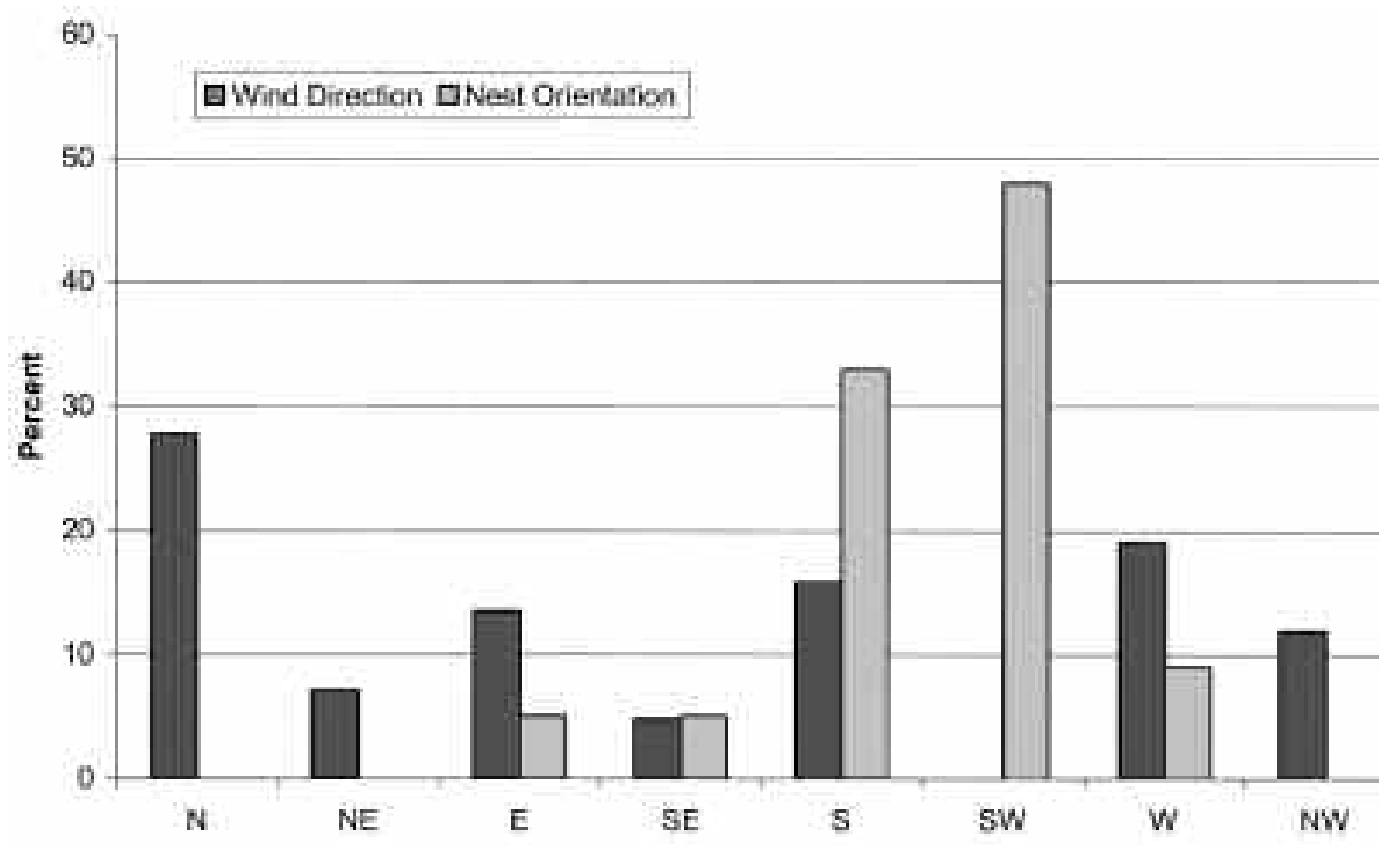

FIGURE 1. Percent of time the prevailing wind blew from the indicated directions and percent of Lapland Longspur nests with an orientation in the indicated direction at Wapusk National Park, Cape Churchill, Manitoba, 2003.

The inner dimensions of Lapland Longspur nests were $64.4 \mathrm{~mm} \pm 3.9 \mathrm{~mm}(n=11)$ wide and $34.7 \mathrm{~mm}$ $\pm 4.6 \mathrm{~mm}(n=6)$ deep. Nests averaged $5.7 \mathrm{~cm} \pm 2.2 \mathrm{~cm}$ above the base of their structures, which was approximately midway (mean $=55.1 \% \pm 17.4 \%$ ) up the nest structure (e.g., pressure ridge). The slope at nests $(30.1 \% \pm 17.8 \%)$ appeared to be greater than random $(17.0 \% \pm 13.8 \%)$ (difference of means $=13.1 \% \pm 25.6 \%$; $95 \% \mathrm{CI}=1.4 \%$ to $24.7 \%$ ). Orientation of longspur nests was not random $(z=13.252, P<0.001$; Rayleigh's test for uniformity); longspur nests had a distinctive southwest orientation $\left(\right.$ mean $=208^{\circ} \pm 39^{\circ} ; 95 \%$ CI of $193^{\circ}$ to $\left.223^{\circ}\right)$. Forty-eight percent of nests had a southwest orientation, and $33 \%$ had a southerly orientation (Figure 1). Winds were primarily from the north (28\%), then west (19\%), south (16\%) and east (13\%) (Figure 1).

Vegetation at the microhabitat scale of the nest $\left(400 \mathrm{~cm}^{2}\right)$ consisted primarily of willow (primarily Salix arctophila; $21.8 \%$ ), graminoids (primarily Carex aquatilis; $18.9 \%)$, moss (10.3\%), litter (12.8\%), Lapland Rosebay (Rhododendron lapponicum; 10.6\%), Dwarf Birch (Betula glandulosa; 7.6\%), and Bog Rosemary (Andromeda polifolia L.; 7.3\%). Species occurring at lower frequency included Bearberry (Arctostaphylos spp.; 2.1\%) Black Crowberry (Empetrum nigrum; $2.0 \%$ ), Dry-ground Cranberry (Vaccinium vitis-idaea; $1.4 \%$ ), Dwarf Labrador Tea (Ledum decumbens; $2.4 \%$ ), White Mountain-avens (Dryas inte- grifolia; $0.3 \%$ ), and Cloudberry (Rubus chamaemorus; $0.2 \%$ ). Based on 95\% C.I.s, it appears Lapland Longspurs selected nest sites that had a comparatively greater amount of willow, Dwarf Birch, and Lapland Rosebay, and lesser amounts of moss (Table 1).

Lapland Longspur nests were generally well concealed by vegetation (mean $=67.0 \% \pm 22.4 \% ; 95 \%$ $\mathrm{CI}=56.7-77.2$ ). Nest concealment appeared to be negatively associated with amount of sedge at the nest. When an obvious outlier was removed, correlation analysis indicated a convincing negative relationship between amount of sedge at nest sites and nest concealment $(r=-0.705, P=0.0005)$. This relationship was still apparent if the outlier was included $(r=-0.474$, $P=0.0298$ ).

\section{Discussion}

Lapland Longspurs appeared to be most abundant on wet lowlands and hummocky tundra cover types (Williamson and Emison 1971; Hussell and Holroyd 1974; Montgomerie et al. 1983; Henry and Mico 2002; Hussell and Montgomerie 2002). Density estimates of the species vary both temporally and spatially. For example, average density at Barrow, Alaska, was 75 pairs $/ \mathrm{km}^{2}$ over a 19 -year period, but was as high as 200 pairs $/ \mathrm{km}^{2}$ (Custer and Pitelka 1977). Spatially, density estimates from North America range from 17 to 200 pairs $/ \mathrm{km}^{2}$ (Hussell and Montgomerie 2002). Although interpretations of the density estimates in this 
TABLE 1. Mean percent cover $( \pm$ SD) of primary vegetative cover types at Lapland Longspur nests $(n=21)$ and paired sites, and mean $( \pm$ SD) difference and 95\% Confidence Interval for mean difference, Wapusk National Park, Cape Churchill, Manitoba, 2003.

\begin{tabular}{lrrrrrrr}
\hline \hline & \multicolumn{2}{c}{ Nest } & \multicolumn{2}{c}{ Pair } & \multicolumn{2}{c}{ Difference } & \multicolumn{2}{c}{$95 \%$ C.I. for } \\
Species & $\bar{x}$ & SD & $\bar{x}$ & SD & $\bar{x}$ & SD & mean difference \\
\hline Willow/Birch & 29.4 & 20.7 & 19.5 & 19.3 & 9.9 & 20.8 & 0.4 to 19.4 \\
Sedge & 18.9 & 18.5 & 18.8 & 12.1 & 0.0 & 19.6 & -8.9 to 9.0 \\
Moss & 10.3 & 13.8 & 34.7 & 23.4 & -24.4 & 19.8 & -33.4 to -15.3 \\
Litter & 15.0 & 8.5 & 15.1 & 11.0 & -0.1 & 10.0 & -4.6 to 4.5 \\
Lapland Rosebay & 10.6 & 19.1 & 1.3 & 3.2 & 9.3 & 16.3 & 1.9 to 16.7 \\
Bog Rosemary & 7.3 & 8.2 & 5.9 & 7.4 & 1.3 & 11.4 & -3.8 to 6.5 \\
Miscellaneous & 8.5 & 12.6 & 4.6 & 7.8 & 3.9 & 15.3 & -3.1 to 10.9 \\
\hline \hline
\end{tabular}

study must be made cautiously due to little spatial and no temporal replication, Lapland Longspur density at the study site (e.g., 82 pairs $/ \mathrm{km}^{2}$ ) does not appear to be outside reasonable expectations. In comparison, however, the current estimated density of longspurs at Churchill was 2.7 to 4.2 pairs $/ \mathrm{km}^{2}$ (J. Jehl, personal communication).

Henry and Mico (2002) found Lapland Longspurs on Banks Island, Northwest Territories, were most common in HT and GST and GRT. Although they did not examine nest sites, the pattern of distribution of birds seemed to be similar to the landscape types in which we found longspur nests. More notable is that regardless of cover type, all longspur nests but one were built into pressure mounds or ridges, even in the lower-lying graminoid-dominated cover types.

Qualitatively, Lapland Longspur nests were cups woven of dead graminoids and thickly lined with feathers and, to a lesser extent, mammal hair which is consistent with reports from other studies (Hussell and Montgomerie 2002). Inner dimensions of Lapland Longspur nests at Cape Churchill were similar to four nests measured at Churchill $($ mean $=67.5 \mathrm{~mm}$; Grinnell 1944) and 22 nests in Greenland (mean $=63.5 \mathrm{~mm}$; Madsen 1981). Inner dimension of 21 nests at Hooper Bay, Alaska, ranged from 76 to $89 \mathrm{~mm}$ (Brandt 1943), which is inexplicably one to two $\mathrm{cm}$ greater than that reported elsewhere. Cup depth of longspur nests in our study $(34.7 \mathrm{~mm})$ was noticeably shallower than the $42.0 \mathrm{~mm}$ reported by Madsen (1981), the $45 \mathrm{~mm}$ reported by Grinnell (1944), or the 64 to $89 \mathrm{~mm}$ reported by Brandt (1943). The reason for the differences in depth may have to do with sample sizes, variability of samples, or with latitude of study. This study and that of Grinnell (1944) were near the southern extent of the species' breeding range and consisted of the smallest sample sizes. The potential for harsher summer weather conditions at more northerly latitudes (Brandt 1943; Madsen 1981) may have led to longspurs building nests with deeper, and thus more thermally protected, cups.

Qualitative descriptions suggest Lapland Longspur nests are typically oriented southeast to southwest (Wil- liamson 1968, Hussell in Hussell and Montgomerie 2002). Williamson (1968) suggested Lapland Longspurs may orient their nests so that the entrances are opposite from the prevailing winds and receive greater insulation. Also, Lapland Rosebay is more profuse on south slopes (J. Jehl, personal communication) and longspurs in this study appeared to select that shrub as nesting cover. Another explanation is that southfacing sides of hummocks may be free of snow earlier than other orientations (Hussell and Montgomerie 2002). On the Arctic Coastal Plain of Alaska, Rodrigues (1994) found that Lapland Longspur nests placed on the side of a ridge, polygon rim, or tussock ( $61 \%$ of nests) had a significant south - southwest orientation. However, $39 \%$ of the nests he located were placed in the open with no detectable orientation. The distinctive southwest orientation of nests in our study supports the earlier descriptions (Williamson 1968; Hussell and Montgomerie 2002) and research results (Rodrigues 1994) indicating Lapland Longspurs do not randomly orient their nests but select for a southerly exposure.

Lapland Longspur nests are subject to depredation by numerous species (Hussell 1974; Hussell and Holroyd 1974; Custer and Pitelka 1977; Fox et al. 1987). Nest concealment, especially from visual predators [e.g., Parasitic Jaeger (Stercorarius parasiticus), Snowy Owl (Bubo scandiacus)], may be an important aspect of nesting success. Nests in our study area were typically well-concealed by overhanging vegetation and, in many cases, were quite difficult to locate visually. Concealment of nests seemed to be enhanced by herb and shrub species, whereas nests dominated by graminoid cover tended to be more exposed. Unfortunately, due to logistical constraints, we were unable to assess possible relationships between nest concealment and nesting failure.

Nest microhabitat vegetation usually consisted of several species, primarily shrub (e.g., willow, birch), woody forbs (e.g., Lapland Rosebay), sedges (e.g., Carex aquatilis) and a mixture of herbaceous species. It appears that longspurs may have preferred sites with shrub and woody forb cover for nesting, but graminoid cover was not used disproportionate to availability. 
Similarly, Rodrigues (1994) found shrub and forb cover was significantly higher at nest sites than random sites, but association with sedge cover was less clear.

Although Lapland Longspurs appear to be an abundant species (Hussell and Montgomerie 2002), the breeding distribution is north of regions covered by the Breeding Bird Survey (Dunn 1997). Monitoring the species across its breeding range is impractical, but trend information may be gleaned through development of several selected long-term monitoring sites. Wapusk NP may provide such a site for long-term monitoring for two reasons. First, the study site in Wapusk NP is located only $35 \mathrm{~km}$ east of Churchill, Manitoba, an area that has experienced substantial declines in Lapland Longspurs (Hussell and Montgomerie 2002). In contrast to declines at Churchill, survey data at the study site in Wapusk NP suggest the species is stable or has possibly increased from 1984 to 2000 (Sammler 2001). Second, the study area is experiencing increasing amounts of habitat alteration through overgrazing by Snow Geese (Chen caerulescens). Breeding populations of Snow Geese have experienced dramatic growth in much of the North American Arctic (Ankney 1996), leading to increased densities at tundra breeding colony sites and a corresponding degradation of vegetation by overgrazing (Kerbes et al. 1990; Abraham and Jefferies 1997; Jano et al. 1998). As Snow Geese have degraded their preferred foraging areas (i.e., salt marshes), they have started foraging in inland freshwater sedge meadows (Abraham and Jefferies 1997) such as those where this study was conducted. Snow Goose-associated habitat alteration has led to declines of some species in the Cape Churchill area (Abraham and Jefferies 1997). More specific to our study site, Lapland Longspurs were detected at lower densities in degraded freshwater sedge meadows compared to meadows that have not been impacted by Snow Geese (Sammler 2001). Thus, monitoring Lapland Longspurs at the study site in Wapusk NP may provide insight into the potential impact Snow Goose population increases may have on breeding density and reproduction of the species and other interior nesting tundra species.

\section{Acknowledgments}

We thank Murray Gillespie for logistical coordination, support, and facilitating our research at the Nester One field site while providing the opportunity to engage in this project. Nestor One is supported through the Eastern Prairie Population (EPP) Technical Section of the Mississippi Flyway Council. Steve Maxson, David Best, Kevin Doherty, Robert Nack, Jeff Dittrich, Mike Schroer, Tom Smith, Bruce Golden, and Michelle McDowell conducted nest searches across the entire study area as part of EPP monitoring efforts. We appreciate the researchers and staff at the Wapusk National Park and Churchill Northern Research Center for support, and the USGS-BRD Minnesota and Texas Co- operative Research Units for providing travel funds. We thank Geoff Holroyd and Joseph Jehl Jr. for their insightful and constructive comments on the manuscript.

\section{Literature Cited}

Abraham, K. F., and R. L. Jefferies. 1997. High goose populations: causes, impacts, and implications. Pages 7-72 in Arctic ecosystems in peril: report of the arctic goose habitat working group. Edited by B. D. J. Batt. Arctic goose joint venture special publication. United States Fish and Wildlife Service, Washington, D.C., USA, and Canadian Wildlife Service, Ottawa, Ontario, Canada.

Ankney, C. D. 1996. An embarrassment of riches: too many geese. Journal of Wildlife Management 60: 217-223.

Baicich, P. J., and C. J. O. Harrison. 1997. A guide to the nests, eggs, and nestlings of North American birds. Academic Press, San Diego, California.

Brandt, H. 1943. Alaska bird trails. Bird Research Foundation, Cleveland, Ohio.

Custer, T. W., and F. A. Pitelka. 1977. Demographic features of a Lapland Longspur population near Barrow, Alaska. Auk 94: 505-525.

Didiuk, A. B., and D. H. Rusch. 1979. Ecology of broods of Canada Geese in northern Manitoba. Wisconsin Cooperative Wildlife Research Unit, Madison, Wisconsin.

Dunn, E. H. 1997. Setting priorities for conservation, research and monitoring of Canada's landbirds. Canadian Wildlife Service, Technical Report Series number 293.

Fox, A. D., I. S. Francis, J. Madsen, and J. M. Stroud. 1987. The breeding biology of the Lapland Bunting Calcarius lapponicus in West Greenland during two contrasting years. Ibis 129: 541-552.

Gilg, O., R. Sane, D. V. Solovieva, V. I. Pozdnyakov, B. Sabard, D. Tsanos, C. Zockler, E. G. Lappo, E. E. Syroechkovski, and G. Eichhorn. 2000. Birds and mammals of the Lena Delta Nature Reserve, Siberia. Arctic 53: 118-133.

Grinnell, L. I. 1944. Notes on breeding Lapland Longspurs at Churchill, Manitoba. Auk 61: 554-560.

Henry, J. D., and M. Mico. 2002. Relative abundance, habitat use, and breeding status of birds in Aulavik National Park, Banks Island, Northwest Territories. Canadian Field-Naturalist 116: 393-407.

Hussell, D. J. T. 1974. Photographic records of predation at Lapland Longspur and Snow Bunting nests. Canadian FieldNaturalist 88: 503-506.

Hussell, D. J. T., and G. L. Holroyd. 1974. Birds of the Truelove Lowland and adjacent areas of northeastern Devon Island, N.W.T. Canadian Field-Naturalist 88: 197-212.

Hussell, D. J. T., and R. Montgomerie. 2002. Lapland Longspur (Calcarius lapponicus). Pages 1-32 in The birds of North America, Number 656. Edited by A. Poole and F. Gill. The birds of North America, Inc., Philadelphia, Pennsylvania.

Jano, A. P., R. L. Jefferies, and R. F. Rockwell. 1998. The detection of vegetational change by multitemporal analysis of LANDSAT data: the effects of goose foraging. Journal of Ecology 86: 93-99.

Jehl, J. R., Jr., and B. A. Smith. 1970. Birds of the Churchill region, Manitoba. Special Publication, number 1, Manitoba Museum of Man and Nature.

Johnson, K. L. 1987. Wildflowers of Churchill and the Hudson Bay region. Manitoba Museum of Man and Nature, Winnipeg, Manitoba, Canada. 
Johnson, D. H. 1999. The insignificance of statistical significance testing. Journal of Wildlife Management 63: 763-772.

Kerbes, R. H., P. M. Kotanen, and R. L. Jefferies. 1990. Destruction of wetland habitats by lesser snow geese: a keystone species on the west coast of Hudson Bay. Journal of Applied Ecology 27: 242-258.

Madsen, J. 1981. Lapland Bunting (Calcarius lapponicus). Pages 183-187 in Report of the 1979 Greenland Whitefronted Goose study expedition to Eqalungmiut Nunat, West Greenland. Edited by A. D. Fox and D. A. Stroud. University College of Wales, Aberystwyth.

Montgomerie, R. D., R. V. Cartar, R. L. McLaughlin, and B. Lyon. 1983. Birds of Sarcpa Lake, Melville Peninsula, Northwest Territories: breeding phonologies, densities and biogeography. Arctic 36: 65-75.

Rising, J. D. 1996. A guide to the identification and natural history of the sparrows of the United States and Canada. Academic Press, San Diego, California.

Rodrigues, R. 1994. Microhabitat variables influencing nestsite selection by tundra birds. Ecological Applications 4: 110-116.

Sammler, J. E. 2001. Population trends of tundra-nesting birds in Churchill, Manitoba: potential effects of increasing lesser snow goose (Chens caerulescens caerulescens) populations. Thesis, University of Minnesota, St. Paul, Minnesota.

Taverner, P. A., and G. M. Sutton. 1934. The birds of Churchill, Manitoba. Annals of the Carnegie Museum 23: 1-83.

Watson, A. 1957. Birds of the Cumberland Peninsula, Baffin Island. Canadian Field-Naturalist 100: 396-397.

Williamson, F. S. L. 1968. Calcarius lapponicus lapponicus (Linnaeus), Common Lapland Longspur; Calcarius lapponicus alascencis (Ridgway), Alaska Longspur. Pages 1597-1627 in Life histories of North American cardinals, grosbeaks, buntings, towhees, finches, sparrows, and allies. Edited by O. L. Austin, Jr. U.S. National Museum Bulletin 237.

Williamson, F. S. L., and W. B. Emison. 1971. Variation in the timing of breeding and molt of the Lapland Longspur (Calcarius lapponicus) in Alaska, with relation to differences in latitude. Bioscience 21: 701-707.

Zar, J. H. 1999. Biostatistical analysis ( $4^{\text {th }}$ edition). Prentice Hall, Inc., Upper Saddle River, New Jersey.

Received 23 April 2004

Accepted 17 March 2005 